\title{
KEBIJAKAN PENDIDIKAN DASAR DALAM PERSPEKTIF PEMBELAJARAN TEMATIK
}

\author{
Anwar Sadat \\ Institut Agama Islam (IAI) Muhammadiyah Bima \\ Email : anwarbinmalik18@gmail.com
}

\begin{abstract}
Abstrak
Penulisan artikel ini menjelaskan Salah satu hal yang mendasar dalam pengembangan kualitas pendidikan adalah adanya kebijakan dari pemerintah terkait dengan proses pelaksanaan pendidikan yang lebih baik. Adapun kebijakan yang dikeluarkan oleh pemerintah yakni perubahan kurikulum dari KTSP ke Kurikulum 2013. Kurikulum merupakan salah satu kompenen inti proses pendidikan. Kurikulum 2013 di SD/MI menggunakan pendekatan pembelajaran tematik dari kelas I sampai kelas VI. Pembelajaran tematik merupakan pendekatan pembelajaran yang mengintegrasikan berbagai kompetensi dari berbagai mata pelajaran ke dalam berbagai tema. Pengintegrasian tersebut dilakukan dalam dua hal, yaitu integrasi sikap, keterampilan dan pengetahuan dalam proses pembelajaran dan integrasi berbagai konsep dasar yang berkaitan. Tema merajuk berbagai makna berbagai konsep dasar sehingga peserta didik tidak belajar konsep dasar secara parsial. Dengan demikian, pembelajaran memberikan makna yang utuh kepada peserta didik seperti tercermin pada berbagai tema yang tersedia.

Kata Kunci : Kebijakan, Pendidikan Dasar, Tematik
\end{abstract}

\section{PENDAHULUAN}

$\mathrm{P}$

ada tahun 2013 pemerintah telah mencanangkan kurikulum 2013

yang saat ini sudah diaplikasikan, pada kurikulum 2013 terdapat

beberapa perbedaan yang signifikan dari kurikulum sebelumnya.

Salah satunya adalah dimunculkannya pembelajaran tematik yang menggunakan tema untuk mengaitkan beberapa mata pelajaran sehingga dapat memberikan pengalaman bermakna kepada siswa. Tema berperan sebagai pemersatu kegiatan pembelajaran yang memadukan beberapa mata pelajaran sekaligus, pembelajaran tematik ini khususnya ditujukan untuk siswa sekolah dasar tingkat rendah. Proses pembelajaran ini masih bergantung kepada objek-objek konkrit dan pengalaman yang dialami secara langsung. 
Kurikulum 2013 berbeda dari kurikulum-kurikulum sebelumnya, dengan pola pendekatan tematik ini, buku-buku siswa SD/MI tidak lagi dibuat berdasarkan mata pelajaran, namun berdasarkan tema yang merupakan gabungan dari beberapa mata pelajaran yang relevan dengan kompetensi di SD/MI. Hal ini sebagai upaya penyederhanaan, dalam wujud tematik-integratif yang bertujuan mencetak generasi yang siap dalam menghadapi masa depan.

Kurikulum untuk sekarang ini masih memegang peran penting dalam suatu pendidikan sebab sebagai penentuan arah isi dan proses pendidikan yang menentukan kualitas lulusan kelak. Dari tahun ketahun kurikulum mengalami perubahan sejalan dengan kemajuan zaman dan perkembangan ilmu pengetahuan dan teknologi bukan karena pergantian menteri yang selama ini difikirkan oleh masyarakat. Perkembangan kurikulum dipengaruhi juga oleh perkembangan teori dan praktek pendidikan serta variasi aliran-aliran atau teori pendidikan yang dianut pada masanya.

Respon berupa perubahan kurikulum merupakan langkah strategis yang dapat ditempuh pemerintah sebagai pengemban amanat undangundang. Perubahan kurikulum 2013 yang sempat menimbulkan polemik pro dan kontra membuat bingung guru-guru sekolah karena wacana perubahan kurikulum tersebut belum terealisasikan secara jelas. Apalagi dalam perubahan kurikulum tersebut, ada perampingan atau penggabungan beberapa mata pelajaran dalam satu tema yang sering kita sebut sebagai model pembelajaran tematik terpadu. Berdasarkan uraian di atas, penulis akan mencoba menganalisis kebijakan-kebijakan pemerintah tentang pendidikan dasar islam dari perspektif pembelajaran tematik.

\section{TINJAUAN TEORITIS}

\section{Pengertian Analisis Kebijakan Pendidikan}

Kebijakan pendidikan merupakan suatu hal yang pokok untuk menentukan arah dan pedoman dalam penyelenggaraan pendidikan dalam suatu negara. Dalam penyelenggaraan pendidikan di setiap lembaga pendidikan, tidak akan pernah lepas dari suatu kebijakan yang dibuat oleh pemerintah dalam Negara tempat lembaga pendidikan itu berada. 
Pengertian analisis kebijakan pendidikan menurut beberapa ahli adalah (Nanang Fatah, 2014):

1. Patton dan Sawicki mengemukakan bahwa analisis kebijakan adalah suatu rangkaian proses dalam menghasilkan kebijakan.

2. Duncan Mac Rae, mengartikan analisis kebijakan ini sebagai suatu disiplin ilmu sosial terapan yang menggunakan argumentasi rasional dengan menggunakan fakta-fakta untuk menjelaskan, menilai, dan membuahkan pemikiran dalam rangka upaya memecahkan masalah publik.

3. Stockey dan Zekhauser, mengartikan analisis kebijakan sebagai suatu proses rasional dengan menggunakan metode dan teknik yang rasional pula. Selanjutnya mereka mempersempit analisis kebijakan hanya diperuntukkan bagi para pembuat keputusan yang rasional sebagai penentu tujuan kebijakan dan yang menggunakan proses logika dalam menelusuri cara terbaik untuk mencapai suatu tujuan.

4. William Dunn, analisis kebijakan adalah suatu disiplin ilmu sosial terapan yang menggunakan metode inkuiri dan argumentasi berganda untuk menghasilkan dan mendayagunakan informasi kebijakan yang sesuai dalam suatu proses pengambilan keputusan.

Kebijakan pendidikan merupakan keseluruhan proses dan hasil perumusan langkah-langkah strategis pendidikan yang dijabarkan dari visi, misi pendidikan, dalam rangka untuk mewujudkan tercapainya tujuan pendidikan dalam suatu masyarakat untuk suatu kurun waktu tertentu (Tilaar dan Nugroho Riant, 2009).

Defenisi analisis kebijakan yang mutlak rasional tersebut di atas terlalu disederhanakan dan sama sekali tidak realistis. Untuk memperoleh pengertian dasar yang lebih luwes kita perlu mengartikan analisis kebijakan sebagai cara atau prosedur dalam menggunakan pemahaman manusia untuk memecahkan masalah kebijakan (Nanang Fatah, 2013).

\section{Pembelajaran Tematik Terpadu}

1. Pengertian Pembelajaran Tematik

Pembelajaran tematik adalah pembelajaran yang tidak menggunakan "nama-nama disiplin ilmu" sebagai nama mata pelajaran tetapi menggunakan tema-tema tertentu. Tema tersebut merupakan 
pengait dari sejumlah pokok bahasan dalam mata pelajaran atau memadukan beberapa mata pelajaran. Dalam mindset Kurikulum 2013, tema yang digunakan untuk mengaitkan beberapa pokok bahasan dalam satu mata pelajaran disebut tematik (saja) sedangkan teama yang mengikat beberapa pokok bahasan dari sejumlah mata pelajaran yang berbeda disebut "tematik terpadu" (Ahmad Yani, 2014).

Pembelajaran tematik dimaknai sebagai pembelajaran yang dirancang berdasarkan tema-tema tertentu (Trianto Ibnu Badar AlTabany, 2015). Sebagai contoh, tema "Air" dapat ditinjau dari mata pelajaran fisika, biologi, kimia, dan matematika. Lebih luas lagi tema itu dapat ditinjau dari bidang studi lain, seperti IPS, bahasa, dan seni. Pembelajaran tematik menyediakan keluasan dan kedalaman implementasi kurikulum, menawarkan kesempatan yang sangat banyak pada siswa untuk memunculkan dinamika dalam pendidikan. Unit yang tematik dari seluruh bahasa pembelajaran yang memfasilitasi siswa untuk secara produktif menjawab pernyataan yang dimunculkan sendiri dan memuaskan rasa ingin tahu dengan penghayatan secara alamiah tentang dunia di sekitar mereka (Trianto Ibnu Badar Al-Tabany, 2015).

Pembelajaran tematika adalah pembelajaran terpadu yang menggunakan tema untuk mengaitkan beberapa mata pelajaran sehingga dapat memberikan pengalaman bermakna kepada murid. Menurut Poerwadarminta tema adalah pokok pikiran atau gagasan pokok yang menjadi pokok pembicaraan. Pembelajaran tematik merupakan salah satu model pembelajaran terpadu (integrated intruction) yang merupakan suatu sistem yang memungkinkan siswa, baik secara individu maupun kelompok aktif menggali dan menemukan konsep serta prinsip-prinsip keilmuan secara holistik, bermakna dan autentik (Abdul Majid, 2014).

Pembelajaran tematik sebagai model pembelajaran termasuk salah satu tipe/jenis daripada model pembelajaran terpadu. Istilah pembelajaran tematik pada dasaranya adalah model pembelajaran terpadu yang menggunakan tema untuk mengaitkan beberapa mata pelajaran sehingga dapat memberikan pengalaman bermakna kepada siswa (Departemen Pendidikan Nasional, 2006). 
Istilah model pembelajaran terpadu sebagai konsep sering dipersamakan dengan integrated teaching and learning, integrated curiculum approach, a coherent curriculum approach. Jadi berdasarkan istilah tersebut, maka pembelajaran terpadu pada dasarnya lahir salah satunya dari pola pendekatan kurikulum yang terpadu (integrated curriculum approach) (Trianto Ibnu Badar Al-Tabany, 2015).

Istilah lain yang sering kali digunakan untuk menyebut kurikulum terpadu adalah kurikulum interdisipliner. Kurikulum interdisipliner didefenisikan sebagai organisasi kurikulum yang melintas batas-batas mata pelajaran untuk berfokus pada pemasalahan kehidupan yang komprehensip tau studi luas yang menggabungkan berbagai segmen kurikulum ke dalam asosiasi yang bermakna (Trianto Ibnu Badar AlTabany, 2015).

Berdasarkan berbagai defenisi sebagaimana yang telah dikemukakan tersebut, pada dasarnya mendukung bahwa kurikulum terpadu adalah pendekatan edukasional yang mempersiapkan siswa untuk menghadapi pembelajaran seumur hidup. Terdapat kepercayaan yang kuat di antara mereka yang mendukung integrasi kurikulum, bahwa sekolah harus memandang pendidikan sebagai proses mengembangkan kemampuan yang dibutuhkan dalam kehidupan di abad ke-21, bukan mata pelajaran discrete yang terbagi-bagi dalam departemen yang berbeda. Dengan demikian, secara umum seluruh defenisi kurikulum terpadu atau kurikulum interdisipliner mencakup:

a. Kombinasi mata pelajaran,

b. Penekanan pada proyek,

c. Sumber di luar buku test,

d. Keterkaitan antar konsep,

e. Unit-unit tematiK sebagai prinsip-prinsip organisasi,

f. Jadual yang fleksibel, dan

g. Pengelompokan siswa yang fleksibel (Trianto Ibnu Badar Al-Tabany, 2015).

Selepas dari berbagai defenisi mengenai kurikulum terpadu yang kemudian melahirkan model pembelajaran yang terkait dengan istilah pembelajaran terpadu. Konsep pembelajaran terpadu pada dasarnya telah 
lama dikemukakan oleh John Dewey sebagai upaya untuk mengintegrasikan perkembangan dan pertumbuhan (Sa'ud Udin Syaefuddin, 2006). Ia memberikan pengertian bahwa pembelajaran terpadu adalah pendekatan untuk mengembangkan pengetahuan siswa dalam pembentukan pengetahuan berdasarkan pada interaksi dengan lingkungan dan pengalaman kehidupannya. Hal ini membantu siswa untuk belajar menghubungkan apa yang telah dipelajari dan apa yang sedang dipelajari.

2. Karakteristik Pembelajaran Tematik

a. Berpusat pada siswa

Pembelajaran tematik berpusat pada siswa (student centered). Hal ini sesuai dengan pendekatan belajar modern yang lebih banyak menempatkan siswa sebagai subjek belajar, sedangkan guru lebih banyak berperan sebagai fasilitator yang memberikan kemudahan-kemudahan kepada siswa untuk melakukan aktivitas belajar.

b. Memberikan pengalaman langsung

Pembelajaran tematik dapat memberikan pengalaman langsung kepada siswa (direct experiences). Dengan pengalaman langsung ini, siswa dihadapkan pada sesuatu yang nyata (konkret) sebagai dasar untuk memahami hal-hal yang lebih abstrak.

c. Pemisahan mata pelajaran tidak begitu jelas

Dalam pembelajaran tematik pemisahan antara mata pelajaran menjadi tidak begitu jelas. Fokus pembelajaran diarahkan kepada pembahasan tema-tema yang paling dekat berkaitan dengan kehidupan siswa.

d. Menyajikan konsep dari berbagai mata pelajaran

Pembelajaran tematik menyajikan konsep-konsep dari berbagai mata pelajaran dalam suatu proses pembelajaran. Dengan demikian, siswa mampu memahami konsep-konsep tersebut secara utuh. Hal ini diperlukan untuk membantu siswa dalam memecahkan masalah-masalah yang dihadapi dalam kehidupan sehari-hari. 
e. Bersifat fleksibel

Pembelajaran tematik bersifat luwes (fleksibel) di mana guru dapat mengaitkan bahan ajar dari satu mata pelajaran dengan mata pelajaran yang lainnya, bahkan mengaitkan dengan kehidupan siswa dan keadaan lingkungan di mana sekolah dan siswa berada.

f. Menggunakan prinsip belajar sambil bermain dan menyenangkan (Abdul Majid, 2014).

3. Manfaat Tematik

Bagi sekolah dasar yang menganut sistem guru kelas, tematik akan memberikan banyak keuntungan antara lain:

a. Fleksibilitas pemanfaatan waktu dan menyesuaikan dengan kebutuhan siswa.

b. Menyatukan pembelajaran siswa, konvergensi pemahaman yang diperoleh sambil mencegah terjadinya inkonsistensi antara mata pelajaran.

c. Merefleksikan dunia nyata yang dihadapi anak di rumah dan lingkungannya.

d. Selaras dengan cara anak berpikir, di mana menurut penelitian otak mendukung teori pedagogik dan psikologi bahwa anak menerima banyak hal dan mengolah, merangkum menjadi satu. Sehingga mengajarkannya secara holistik terpadu adalah sejalan dengan bagaimana otak anak mengolah informasi (Daryanto, 2014).

\section{PEMBAHASAN}

\section{Kemampuan Guru tentang Pembelajaran Tematik}

Pembelajaran tematik merupakan gabungan antara berbagai bidang kajian, misalnya bidang IPA, Matematika, Pendidikan Agama, IPS, dan lainnya. Maka dalam pelaksanaannya tidak lagi terpisah-pisah melainkan menjadi satu kesatuan (holistic) dan keterpaduan (integralistic). Hal ini memberi implikasi terhadap guru yang mengajar di kelas. Menurut Depdiknas bahwa pembelajaran tematik memerlukan guru yang kreatif baik dalam menyiapkan kegiatan/pengalaman belajar bagi 
anak, juga dalam memilih kompetensi dari berbagai mata pelajaran dan mengaturnya agar pembelajaran menjadi lebih bermakna, menarik, menyenangkan dan utuh (Trianto Ibnu Badar Al-Tabany, 2015).

Pelaksanaan pembelajaran tematik tiap hari dilakukan dengan menggunakan tiga tahap kegiatan. Jadi guru harus bisa membagi waktu dengan baik. Di mana tiga tahap kegiatan tersebut adalah kegiatan pembuka/awal/pendahuluan, kegiatan inti dan kegiatan penutup. Alokasi waktu untuk setiap tahapan adalah kegiatan pembuka lebih kurang 5-10\% waktu pelajaran yang disediakan, kegiatan inti lebih kurang $80 \%$ dari waktu pelajaran yang telah disediakan, sedangkan kegiatan penutup dilaksanakan dengan alokasi waktu lebih kurang 10-15\% dari waktu pelajaran yang disediakan. Pada ketiga tahap tersebut, guru harus bisa memanfaatkan waktu pembelajaran dengan baik. Agar tujuan pembelajaran dapat tercapai dan anak didik menjadi anak yang cerdas dan berpotensi di masa yang akan datang (Trianto Ibnu Badar Al-Tabany, 2015).

Guru harus mampu membuat media pembelajaran. Yang mana sebelum membuat media pembelajaran tematik, langkah kritis pertama yang perlu dilakukan guru dalam membuat media adalah mencari, menemukan, dan memilih media yang memenuhi kebutuhan belajar anak, menarik minat anak, sesuai dengan perkembanagn kematangan dan pengalaman. Dan dengan sendirinya harus sesuai dengan subjek yang dipelajari. Oleh karena itu, prinsip utama pemilihan media harus didasarkan pada tujuan belajar yang ditentukan dengan mengingat karakteristik khusus yang ada pada kelompok belajar (Trianto Ibnu Badar Al-Tabany, 2015).

Guru harus berwawasan luas, memiliki kreativitas tinggi, keterampilan metodologis yang handal, rasa percaya diri yang tinggi, dan berani mengemas dan mengembangkan materi. Secara akademik, guru dituntut untuk terus menggali informasi ilmu pengetahuan yang berkaitan dengan materi yang akan diajarkan dan banyak membaca buku agar penguasaan bahan ajar tidak terfokus pada bidang kajian tertentu saja. Tanpa kondisi ini, pembelajaran terpadu akan sulit terwujud. 
Pengelolaan pembelajaran dapat optimal apabila guru mampu menempatkan dirinya dalam keseluruhan proses. Artinya, guru harus mampu menempatkan diri sebagai fasilitator dan mediator dalam proses pembelajaran. Oleh sebab menurut Prabowo, bahwa dalam pengelolaan pembelajaran hendaklah guru dapat berlaku sebagai berikut:

1. Guru hendaknya jangan menjadi single actor yang mendominasi pembicaraan dalam proses belajar mengajar.

2. Pemberian tanggung jawab individu dan kelompok harus jelas dalam setiap tugas yang menuntut adanya kerja sama kelompok.

3. Guru perlu mengakomodasi terahadap ide-ide yang terkandung sama sekali tidak terpikirkan dalam perencanaan.

Guru harus mampu membuat penilaian pembelajaran tematik. Penilaian dalam pembelajaran tematik adalah suatu usaha untuk mendapatkan berbagai informasi secara berkala, berkesinambungan, dan menyeluruh tentang proses dan hasil dari pertumbuhan dan perkembanagn yang telah dicapai oleh anak didik melalui program kegiatan belajar.

Penilaian merupakan pengumpulan informasi untuk menentukan kualitas dan kuantitas peserta didik. Guru dalam penilaian bisa mengumpulkan informasi tentang berbagai hal yang terkait dengan pencapaian peserta didik melalui berbagai bentuk tes atau non tes. Melalui penilaian guru dapat menentukan apakah peserta didik mengalami kemajuan dalam belajar ataupun menguasai kompetensi yang diharapkan. Penilaian diharapkan juga bermanfaat bagi peserta didik utamanya agar peserta didik mengetahui kemajuan belajarnya, lebih termotivasi untuk belajar dan lebih bertanggung jawab terhadap keberhasilan belajarnya (Trianto Ibnu Badar Al-Tabany, 2015).

\section{Analisis Kebijakan Pendidikan Dasar Dalam Perspektif Pembelajaran Tematik}

Apabila dikaitkan dengan tingkat perkembangan anak, pembelajaran terpadu merupakan pendekatan pembelajaran yang memperhatikan dan menyesuaikan pemberian konsep sesuai dengan tingkat perkembangan anak. Pendekatan berangkat dari teori pembelajaran yang menolak drill-system sebagai dasar pembentukan 
pengetahuan dan struktur intelektual anak (Trianto Ibnu Badar Al-Tabany, 2015).

Pembelajaran tematik/terpadu menawarkan model-model pembelajaran yang menjadikan aktivitas pembelajaran itu relevan dan penuh makna bagi siswa, baik aktivitas formal maupun informal, meliputi pembelajaran inquiri secara aktif sampai dengan penyerapan pengetahuan dan fakta secara pasif, dengan memberdayakan pengetahuan dan pengalaman siswa untuk membantunya mengerti dan memahami dunia kehidupannya. Cara pengemasan pengalaman belajar yang dirancang oleh guru yang demikian akan sangat berpengaruh terhadap kebermaknaan pengalaman siswa dan menjadikan proses pembelajaran lebih efektif dan menarik. Kaitan konseptual yang dipelajari dengan isi bidang studi lain yang relevan akan membentuk skemata, sehingga akan diperoleh keutuhan dan kebulatan pengetahuan. Perolehan keutuhan belajar, pengetahuan, dan kebulatan pandangan tentang kehidupan dan dunia nyata hanya dapat direfleksikan melalui pembelajaran terpadu (Trianto Ibnu Badar Al-Tabany, 2015).

Pembelajaran tematik sebagai bagian daripada pembelajaran terpadu memiliki banyak keunggulan yang dapat dicapai sebagai berikut:

1. Memudahkan pemusatan perhatian pada satu tema tertentu.

2. Siswa mampu mempelajari pengetahuan dan pengembangan berbagai kompetensi dasar antar isi mata pelajaran dalam tema yang sama.

3. Pemahaman materi mata pelajaran lebih mendalam dan berkesan.

4. Kompetensi dasar dapat dikembangakan lebih baik dengan mengaitkan mata pelajaran lain dengan pengalaman pribadi siswa.

5. Lebih dapat dirasakan manfaat dan makna belajar karena materi disajikan dalam konteks tema yang sama.

6. Siswa lebih bergairah belajar karena dapat berkomunikasi dalam situasi nyata, untuk mengembangkan suatu kemampuan dalam suatu mata pelajaran dan sekaligus dapat mempelajari mata pelajaran lain.

7. Guru dapat menghemat waktu sebab mata pelajaran yang disajikan secara tematik dapat dipersiapkan sekaligus, dan diberikan dalam dua atau tiga pertemuan, dan waktu selebihnya dapat dimanfaatkan untuk 
kegiatan remedial, pemantapan, atau pengayaan materi (Trianto Ibnu Badar Al-Tabany, 2015).

Berdasarkan berbagai pengertian tersebut di atas, dapatlah diambil kesimpulan bahwa pembelajaran tematik/terpadu merupakan suatu model pembelajaran yang memadukan beberapa materi pembelajaran dari berbagai standar kompetensi dan kompetensi dasar dari satu atau beberapa mata pelajaran. Penerapan pembelajaran ini dapat dilakukan melalui tiga pendekatan yakni penentuan berdasarkan keterkaitan standar kompetensi dan kompetensi dasar, tema dan masalah yang dihadapi.

Di mana pembelajaran tematik itu memiliki kelebihan dan kelemahan. Kelebihan pembelajaran tematik sebagai berikut:

1. Menyenangkan karena berangkat dari minat dan kebutuhan anak didik.

2. Memberikan pengalaman dan kegiatan belajar mengajar yang relevan dengan tingkat perkembangan dan kebutuhan anak didik.

3. Hasil belajar dapat bertahan lama karena lebih berkesan dan bermakna.

4. Mengembangkan keterampilan berpikir anak didik sesuai dengan persoalan yang dihadapi.

5. Menumbuhkan keterampilan sosial melalui kerja sama.

6. Memiliki sikap toleransi, komunikasi, dan tanggap terhadap gagasan orang lain.

7. Menyajikan kegiatan yang bersikap nyata sesuai dengan persoalan yang dihadapi dalam lingkungan anak didik (Daryanto, 2014).

Di samping kelebihan, pembelajaran tematik terpadu memiliki keterbatasan terutama dalam pelaksannannya, yaitu pada perancangan dan pelaksanaan evaluasi yang lebih banyak menuntut guru untuk melakukan evaluasi proses, dan tidak hanya evaluasi dampak pembelajaran langsung saja. Aspek keterbatasan pembelajaran terpadu, yaitu sebagai berikut:

1. Aspek guru,

2. Aspek peserta didik,

3. Aspek sarana dan sumber pembelajaran,

4. Aspek kurikulum, dan

5. Aspek penilain (Daryanto, 2014). 


\section{SIMPULAN}

Analisis kebijakan yang mutlak rasional tersebut di atas terlalu disederhanakan dan sama sekali tidak realistis. Untuk memperoleh pengertian dasar yang lebih luwes kita perlu mengartikan analisis kebijakan sebagai cara atau prosedur dalam menggunakan pemahaman manusia untuk memecahkan masalah kebijakan. Pembelajaran tematik adalah pembelajaran yang tidak menggunakan "nama-nama disiplin ilmu" sebagai nama mata pelajaran tetapi menggunakan tema-tema tertentu. Tema tersebut merupakan pengait dari sejumlah pokok bahasan dalam mata pelajaran atau memadukan beberapa mata pelajaran. Dalam mindset Kurikulum 2013, tema yang digunakan untuk mengaitkan beberapa pokok bahasan dalam satu mata pelajaran disebut tematik (saja) sedangkan teama yang mengikat beberapa pokok bahasan dari sejumlah mata pelajaran yang berbeda disebut "tematik terpadu".

Guru harus berwawasan luas, memiliki kreativitas tinggi, keterampilan metodologis yang handal, rasa percaya diri yang tinggi, dan berani mengemas dan mengembangkan materi. Secara akademik, guru dituntut untuk terus menggali informasi ilmu pengetahuan yang berkaitan dengan materi yang akan diajarkan dan banyak membaca buku agar penguasaan bahan ajar tidak terfokus pada bidang kajian tertentu saja. Tanpa kondisi ini, pembelajaran terpadu akan sulit terwujud.

Pembelajaran tematik/terpadu menawarkan model-model pembelajaran yang menjadikan aktivitas pembelajaran itu relevan dan penuh makna bagi siswa, baik aktivitas formal maupun informal, meliputi pembelajaran inquiri secara aktif sampai dengan penyerapan pengetahuan dan fakta secara pasif, dengan memberdayakan pengetahuan dan pengalaman siswa untuk membantunya mengerti dan memahami dunia kehidupannya.

\section{DAFTAR PUSTAKA}

Abdul Majid, 2014, Pembelajaran Tematik Terpadu, Bandung: PT Remaja Rosdakarya.

Ahmad Yani, 2014, Mindset Kurikulum 2013, Bandung: Alfabet.

Daryanto, 2014, Siap Menyongsong Kurikulum 2013, Yogyakarta: Penerbit Gava Media. 
Departemen Pendidikan Nasional, 2006, Panduan Pengembangan Pembelajaran IPA Terpadu, Jakarta, Depdiknas.

Nanang Fatah, 2014, Analisis Kebijakan Pendidikan, Bandung: Remaja Rosdakarya.

Sa'ud Udin Syaefuddin, dkk., 2006, Pembelajaran Terpadu, Bandung: UPI Press.

Sri Anitah, 2013, Pembelajaran Terpadu: Paradigma Konstruktivistik dalam Rangka Pengembangan Kecerdasan Ganda, Surakarta: Sebelas Maret Universitas Press.

Tilaar dan Nugroho Riant, 2009, Kebijakan Pendidikan, Yogyakarta: Pustaka Pelajar.

Trianto Ibnu Badar Al-Tabany, 2015, Desain Pengembangan Pembelajaran Tematik, Jakarta: Kharisma Putra Utama 